\title{
CONTRIBUTION OF THE ARCHPRIESTS RADU TEMPEA II (THE CHRONICLER) AND EUSTACHIE GRID (THE CONSTRUCTOR) AND THE PAINTING OF THE TWO CHAPELS OF ST NICHOLAS CHURCH FROM THE ŞCHEII BRAŞOVULUI, IN THE XVIII ${ }^{\text {TH }}$ CENTURY
}

\author{
Stelian MANOLACHE*
}

\begin{abstract}
The work meeting of the Holy Council of the Romanian Orthodox Church, on the $28^{\text {th }}-29^{\text {th }}$ of October 2016, declared the year of 2017 as a reverential year of the Holy Icons, of the painters of icons, and of the religious painters, marking 1230 years from the Seventh Ecumenical Council (787, Nicaea). In this context, we led our research on the special importance of the Museum of the First Romanian Scholl of Şcheii Braşovului, an old educational institution, reflecting Romanian feelings and thinking, which holds over 40,000 documents, a collection of over 4,000 old books and 300 icons, together with the Church, a historical monument, whose patron is Saint Nicholas. An entire national cultural patrimony coagulated around the Church. Our study pays homage to the scholar priests from the $18^{\text {th }}$ century, who watched over the construction of the two chapels of the Church "Saint Nicholas" of Şcheii Braşovului; edifices with original architecture and impressive paintings of the chapels.
\end{abstract}

Keywords: Orthodoxy, religious-cultural resistance, Church, icons, religious painters.

\section{Preliminaries}

As a unique Orthodox church in the area of Braşov, where there

PhD, Associate Professor, 'Ovidius' University (Department of Orthodox Theology) Constanţa, Romania. 
were four localities of the Romanian people ${ }^{1}$, with indubitable archaeological material proofs ${ }^{2}$, a real Cathedral of the Romanian ${ }^{3}$ from Țara Bârsei, the history of the Church Saint Nicholas of Şcheii Braşovului starts in $1292^{4}$ and reaches the peak of its cultural and religious development in the $18^{\text {th }}$ century. Initially, the old chronicles of Braşov as reverend professor Vasile Oltean shows, "a wooden tile cross was built in Şchei and after many years, instead of the cross, they built a wooden church, having Saint Nicholas as patron and, later, in the year 1518 from Christ, a well-known priest, Petru, together with many people from Şchei, dared to go to Wallachia, to the Lord of the Country, Ioan Neagoe Basarab Voevod, the son of Basarabi, and asked him to build a stone church in Şchei"s. The existence of the first wooden church is confirmed in numerous documents, starting with the Papal Edict of Pope Boniface IX, in $1399^{6}$, which wasintended to convert the Romanian Orthodox people in Şchei to Roman Catholicism. The donation of the family of the king Mihai Viteazul, in 1602, offered to this Orthodox church, under the patronage of The Assumption of Virgin Mary/ Uspenia Precesteia, the estate of Micşuneşti, Wallachia ${ }^{7}$. With all the attempts of the pope of that time, no case of conversion to Catholicism from Orthodoxy in the Church Saint Nicholas of Şcheii Braşovului was confirmed ${ }^{8}$, due to pastoral activity of the Orthodox priests, Costea $(+1477)$ and Pătru cel Bătrân $(+1541)$, devoted to the

${ }^{1}$ Gernot Nussbacher, Caietele Corona-Contribuţii la istoria Braşovului, Caietul 2, Braşov, Aldus, 2003, p. 7. First locality was in the area of the contemporary district Şchei, another in the Norh of Cetăţuia Hill, the third was in the West of Şprenghi Hill and the fourth in the area of the contemporary district Valea Cetăţii.

2 Ioan POP, "Date arheologice privitoare la istoria Braşovului în secolele IX-XII", in Cummidava II, Braşov, 1968, p. 9-26; Gernot NussbaCHER, Caietele CoronaContribuţii la istoria Braşovului, Caietul 2, Braşov, Aldus, 2003, p. 11.

3 Vasile Oltean, Configuraţia istorică şi bisericească a Braşovului (sec XIII-XX),

Sibiu, 'Andreiană' Ph., 2010, p.193.

${ }^{4}$ Vasile Oltean, Configuraţia istorică ..., p. 194.

${ }^{5}$ Ibidem.

6 Vasile OlteAn, Şcoala românească din Şcheii Braşovului, Bucureşti, Ştiinţifică şi Enciclopedică Ph., 1989, p. 14.

7 Ioan LuPAŞ, Documente istorice transilvănene, vol I, Cluj, Tipografia Cartea Românească, 1940, p. 73-77; Vasile Oltean, Moartea lui Mihai Viteazul, Braşov, Ermetic, 2001, p. 66-67;

${ }^{8}$ Vasile Oltean, Configuraţia istorică ..., p. 137. 
nation and to their faith, as ${ }^{9}$. Research initiated at the Direction of the Historical Monuments, between 1969 and 1975, by Mariana Angelescu and Alexandru Dobriceanu ${ }^{10}$, Eugenia Greceanu ${ }^{11}$, Luminiţa Munteanu and Mariana Beldie ${ }^{12}$, confirm the existence of a wooden church and of other two religious buildings. From the two other constructions, the first is a stone church from c. 1440, the chronicles mentioning that "in 1495, the good Christians from here went to the Honourable Council with the big request and the big honour from I Neagoe Voevod of Wallachia and the Council allowed the building of the stone church, with the help of Neagoe Voevod, and also with help from the citizens, either old or young, rich or poor, small or important, finishing the Holy Altar, the patronage and the old steeple"13. At that time, the ruler of Wallachia was not Neagoe Voevod, but Vlad Călugărul/Pahomie - as Nicolae Iorga mentions - which, taking refuge with the Romanians from Şcheii Braşovului and returning as ruler in Wallachia, showed his gratitude to the citizens from Şchei, who sheltered him during his persecution. This is the main reason for his help in the building of a stone church. Research developed between 1978 and 1988, initiated by the Direction of the Historical Monuments, show that the ruler of Wallachia, Neagoe Basarab, supported the construction of a third religious building after a plan similar to the previous stone church, with a polygonal apse, axed edges and three abutments ${ }^{14}$. Well-known merchants and future rulers of Wallachia, Petru Cercel and Aron Vodă of Moldavia helped the building of this church. The first managed to build the part of the Church where

${ }^{9}$ Vasile Oltean, Configuraţia istorică ..., p. 194.

10 Mariana Angelescu, Alexandru DobRicEAnu, "O descoperire recentă. Vechiul parament al Bisericii din Şcheii Braşovului”, in Astra, no.5/1968.

11 Eugenia GreceAnu, Pătrunderea infulenţelor de tradiţie bizantină în arhitectura bisericilor româneşti din Transilvania (până la sfârşitul veacului al XVI-lea), in Studii şi Cercetări de Istorie şi Arheologie, no. 2/1972, p. 207-214.

12 Luminiţa MunteAnU / Mariana BELDIE, "Rezultatele cercetărilor arheologice la Biserica Sfântul Nicolae din Şcheii Braşovului - etapa 1975", in Monumente de Istorie şi Arheologie (hereinafter MIA), 1976, no. 1.

13 Candid MuşleA, Biserica Sfântul Nicolae din Şcheii Braşovului, vol I 1292-1742, Astra, Braşov, str. Lungă, nr 1, 1946, p. 53-54.

14 Vasile Olteanu, Configuraţia istorică şi bisericească a Braşovului (sec XIII-XX), Sibiu, Andreiană, 2010, p. 195. 
the women listen to the Word and the foundation tower in $1538^{15}$, similar to the church porch from Târgovişte, and the second is mentioned by the archpriest Vasile in 1628: "what wasn't finished by Petru Vodă, ... Aron Vodă finished and painted and built the tower in 1595, endowing the Church on the inside and on the outside with many

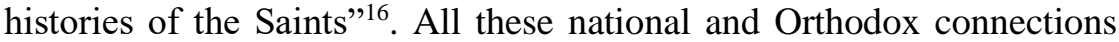
between Transylvania, Wallachia and Moldavia were maintained in time - especially in the $18^{\text {th }}$ century, when major social, political and religious changes appeared - through numerous donations mentioned in several documents, starting with the chronicle of the archpriest Vasile in $1628^{17}$, continued by the de archpriest Radu Tempea II Cronicarul - a chronicle known as published by Sterie Stinghie, Octavian Şchiau and Livia Bot $^{18}$, together with the writings of Nicolae Iorga ${ }^{19}$, Ştefan Meteş, professor Candid Muşlea, from Braşov ${ }^{20}$ and the monumental collection of German documents published in Braşov in 13 volumes $^{21}$.

\section{The Church "Saint Nicholas" in the political and religious context of the $18^{\text {th }}$ century}

The $18^{\text {th }}$ century starts in Europe with two exceptional events, a religious one and a political one. The two events will influence each other as a result of the political, cultural and religious collision between the West, represented by the political power from Wien and the religious power from Rome, and East, represented by the three

${ }^{15}$ Arhiva Muzeului, Register 3, p. 2, cited by C. Muşlea, annex 2, vol. I, Biserica Sfântul Nicolae..., vol. I, p. 60.

${ }^{16}$ Register 2 in Arhiva MuZeului, p. 175.

${ }^{17}$ Nicolae SuliC̆, Cronica protopopului Vasile din Braşov, Sibiu, 1943.

18 Vasile Oltean, Configuraţia istorică şi bisericească a Braşovului (sec XIII-XX), Sibiu, Andreiană, 2010, p. 193; Sterie STINGHE / Octavian ŞCHIAU / Livia Bot, RaduTempea - Istoria sfintei besereci a Şcheilor Braşovului, Bucureşti, Editura pentru Literatură, 1969.

19 Nicolae IORGA, "O descoperire privitoare la Biserica Sfântul Nicolae din Şcheii Braşovului", in Memoriile Academiei Române, secţia Istorică, no. 22/1939, Bucureşti.

${ }^{20}$ Candid MuşleA, Biserica Sfântul Nicolae din Şcheii Braşovului, vol. I: 1292-1742, in Astra, no.1-2, Braşov, 1946.

21 XXX, Quellen...vol. I-VIII: 1886-1926, vol. IX, 2002, apud V. OLTEANU, Configuraţia istorică ..., p. 194. 
Romanian lands and Russia. The events will influence the later sociopolitical evolution of the Romanian, Hungarian and Transylvanian Saxon communities from Transylvania. The influences will act inclusively on the architecture and the paintings from the two regions in conflict, influences that will bring to the nation a definition of confessional and religious identity, which started from a certain religious culture and spirituality. The first event, a religious one, Uniaţia, will try, based on the political events generated by the assault of the Turkish on Wien in 1683, to bring back Catholicism, which lost religious influence due to the Calvinist-Lutheran authority that had ruled in Transylvania. The second event, political and economic, will be started by the duplicitous politics of Leopold I - who established the Habsburg regime - through the Leopoldine Diploma. The Diploma, from the $4^{\text {th }}$ of December 1691, which subordinated Transylvania directly to the Court of Wien, maintained the old political system of the three privileged nations - Szecklers, Saxons and Hungarians - and recognized only four confessions: Catholic, Calvin, Lutheran and Unitarian. According to the Edict of Turda, in 1568, the Romanians were marginalized again politically and religiously. In this context, the Empress Maria Teresa, through General Buckow, continued political and religious oppression of the Romanians, favoring the Calvin Saxon from Braşov. Through the Diploma Leopoldina, Emperor Leopold I, an answer to the memoir of the Orthodox Romanians from Sichei, on the $27^{\text {th }}$ of June 1701, granted them some facilities related to religious and economic life. The Emperor brought to attention of the Magister of Braşov the oppression of the Orthodox Romanians from Şchei, who were paying the maximum amount of taxes: We give our royal advice fully and for stronger certification against the commerce problems. Our special royal advice is for everything and for all the merchants, showing our understanding through the Diploma" ${ }^{22}$. All the recommendations of the Court from Wien were favorable to the inhabitants from Șchei, but were ignored by the ruler of Braşov, which led to complaints from the Romanians against the Saxon administration in 1723, 1733, 1735,1736 şi 1737 . Dominated by the two above events, the duplicitous political

22 Sterie STINGHE, Documente privitoare la trecutul românilor din Şchei 1700-1795, vol. V, Braşov, 1901-1907, p. 7-12. 
imperial and religious power from Wien and Rome, aware of the demographical growth of the Romanians, who were seen as possible future allies, tried to attract to their side the Romanian clergy and population $^{23}$, offering them tax exceptions and the elimination of the serf age. Seduced by the promises, 38 Transylvanian priests, under the leadership of Metropolitan Atanasie Anghel, signed at Alba-Iulia, in October 1698, the act of union with the Church of Rome, an action that started the revolt of Orthodox believers. The inhabitants from Şchei, together with their priests and guardians, declared themselves Orthodox, together with the Greeks from Braşov ${ }^{24}$, who had declared the same religion at the first census in 1698. Concomitantly, the imperial power of Wien put religious and administration pressure on the Saxons from Braşov, which had passed to Lutheranism. Maria Teresa (1740-1780) dictated that half of the people from the Magistrate of Braşov were to be Catholics and Orthodox Romanians were forbidden to build houses between Tohan and Dârste. Under these conditions of duplicitous imperial politics, in order to protect their economic rights and the Orthodox confession, believers from the Church "Saint Nicholas" used, as well, after the political model of the Wien and Rome court, a duplicitous politics, one oriented to the Court of Wien, for the recognition of their economic rights, and one oriented to Wallachia and Russia, for the recognition of the Orthodox confession, as observed in the actions of the scholar prieste Radu Tempea II and Eustachie Grid, the initiators of the building of the two chapels from the Church "Saint Nicholas" from Şcheii Braşovului.

\section{The Chapels of the Church "Saint Nicholas" - a short iconographic evaluation}

In spite of or, better said, as a result of the context, the Church "St. Nicholas" represented in the $18^{\text {th }}$ century the main point of support for the national and religious identity of the Romanians from Ţara Bârsei. The preservation of Romanian ethnicity and of Orthodoxy, is the perspective for the admiration of the efforts in building the two chapels

23 Silviu Dragomir, Istoria dezrobirii religioase a românilor din Ardeal în secolul XVIII, vol. I, Sibiu, Tiparul Tipografic al arhidiacezanei, 1920, p. 3.

${ }^{24}$ Ibidem, p. 17-18. 
by the archpriests Radu Tempea II (1691 - 1742), who, becoming archbishop promised "to be strong [...] and to stay away of the Union [with Rome]", and Eustachie Grid (1721 - 1767), who obtained political and material support for the Church "St. Nicholas" from the Czarina Elisabeta Petrovna $(1741$ - 1762), including her intervention to Maria Teresa for the suspension, at least temporary, of the unionist pressures in Ţara Bârsei.

a) Background. Until the $18^{\text {th }}$ century, the people in Braşov and their main supporters - the ruling families from Wallachia and Moldavia - built to chapels next to the Church of "St. Nicholas". Chronologically, the first one was a wooden small building ${ }^{25}$, mentioned in the Chronicle of the archpriest Radu Tempea II, who showed that Aron Vodă of Moldavia "took the example of the ancient good rulers and painted the chapel and the church porch",26, a detail mentioned also in the Registers (Catastifele) researched by Candid Musslea, where it is written that in the year of 1595, "loving Christ, the ruler of Moldavia, took the example of these good rulers [of Wallachia] and built [...], painting the chapel and the church porch with the divine faces of the saints, in wonderful icons" 27 . A second chapel, this time a stone one, is mentioned as existing since the year of 1651. With St. John the Baptist as patron, the chapel was composed from two small rooms - also with role of vestry. Its mural paintings are nowadays much deteriorated. Still, a series of scenes from the New Testament may be identified - the resurrection of Lazarus, the prayer from the Garden of Gethsemane, the whipping of the Saviour, also faces of angels and saints - St. Stephan, St. Basil. St. Nicholas - surrounded by a rich floral décor with Transylvanian specificity.

b) The Chapel of the Annunciation was built at the beginning of the year1733 by the archpriest Radu Tempea II Cronicarul: "after finishing the copy of the Christian teachings [...], he decides to build [...] a chapel for confessions and other religious services" ${ }^{28}$. The chapel is located on the left of the Church, with the dimensions of $12.60 \mathrm{~m}$. X

25 Ibidem, p. 83.

${ }^{26}$ Sterie StINGHE / Octavian ŞCHIAU / Livia Bot, op. cit., p. 215.

${ }^{27}$ Candid MuşLEA, Biserica Sfântul Nicolae ..., vol. I, p. 79-80.

${ }^{28}$ IDEM, $O$ dinastie de preoţi şi protopopi: Radu Tempea, p. 15. 
$4.50 \mathrm{~m}$. The chapel was later transformed into a funerary chapel, as commanded by the rulers of Braşov. The foundation is set on the $9^{\text {th }}$ of July $1733^{29}$. The construction is supported, in the spirit of the Church "St. Nicholas", by the rulers of Wallachia and the merchants from Braşov, and especially through donations - "a cross with diamonds, priced at $500 \mathrm{fl}$, a larger diamond ring, priced at $15 \mathrm{fl}$, a smaller diamond ring, priced at 100 fl., two solitary diamond rings, priced at 250 fl." - donated through testament by princess Ancuţa $(+1730)$, the daughter of Vodă Brâncoveanu, "to repair and grow the church from Şchei, to her eternal remembrance" 30 . Still, the building of the chapel met opposition just as any other Romanian work of those times. First, the opposition was financial, because the Moldavian noble Nicolaie Ruset, husband of Ancuţa Brâncoveanu, remarried a Catholic woman and converted to Catholicism, also becoming a count; thus, he refused to fulfil the testamentary clauses. A smaller sum was still received by the church. It was more difficult to overcome the opposition of the local Saxon authorities, who permitted construction only after the intervention of Wallachian Grigore Matei Ghica (1752 - 1753) and Constantin Mavrocordat, who ruled six times between 1730 and 1769.

In spite of its reduced dimensions, the chapel is an authentic monument of religious art, which, next to the Byzantine icons found, includes some characteristics of the Wallachian iconography and paintings. Discussing the artistic value of the chapel - "you don't know the treasures on the walls" ${ }^{31}$-, Nicolae Iorga wrote:

"The first [chapel] is especially beautiful [...]. It has a small altar screen charming by candle light through the soft sparkling of the golden sculptures. The frescoes deserve all the attention because they show biblical scenes and illustrations of the parables and of the evangelic teachings. It is the same painting with Wallachian tradition coming from all the passing points in Transylvania; the exterior walls were covered in paintings, as the remains prove $[\ldots]^{\prime 32}$.

Next to the long string, under the form of a triptych, written in

${ }^{29}$ IDEM, Biserica Sfântul Nicolae..., vol. I, p. 197.

30 Vasile Oltean, Configuraţia istorică..., p. 211.

${ }^{31}$ Candid MuşleA, Biserica Sfântul Nicolae..., vol. I, p. 362.

${ }^{32}$ N. IoRGA, Artă nouă şi veche în Ardealul anului încoronării, București, 1923, p. 100. 
1734, it was honoured Constanda lui Manole ${ }^{33}$, a female inhabitant of Şchei, together with other Christians ${ }^{34}$, contributing to the construction of the Chapel. On the eastern wall of the altar, the names of the painters are written: "Ranite Grigorie, Gheorghe, Ion, Mihail, paintersAug [ust] 23 [1737]", who painted also the frescoes in the Church of Tismana Monastery in 1732 and the Church of şi Vlădeni, near Braşov, in $1734^{35}$. On the stone belt of the table of oblation, located in the right corner of the altar, appears the year 1735, and on the icon of the patron is written: "Iconopiseţ Gheorghie painter - 1738". The interior painting is coherent and respects the tradition of the Eastern Church, which is strictly followed by Radu Tempea II Cronicarul. The theme of Jesus Christ Pantokrator is painted on the nave; the Virgin Mary with the Son is painted on Her throne, between two archangels; in the west, there are several scenes related to the Passions of Christ - The Prayer from the Mount of Olives, The Capturing of Christ, Jesus in front of Ana, Jesus in front of Caiafa, the Whipping and The crown of thorns -, special attention is given to the scene of the Resurrection. In the northern apse, the Resurrection is represented and completed with a series of explaining scenes - The Angel telling the women about the Resurrection, The Dinner at Emmaus, Jesus appearing to Magdalene, Peter and John and Thomas Doubting. The painting on the façade of the abutment shows the unique scene of the Earth surrounding the Sun, proving that the painters knew the discoveries of Copernic and Galileo Galilei. The movement of rotations is given to Earth by the Saints of God. The eastern wall of the altar is painted with the vision of the martyr bishop Peter of Alexandria, a symbol of Orthodoxy and an adversary to Arianism; in context, Ari is painted swallowed by the monster of Leviathan - a symbol of the hell. The scene is painted mirrored with the Fathers in the First Ecumenical Council, with the Emperor Constantine in the centre, surrounded by 318 Fathers, dressed in religious ceremonial clothing. The text of the Creed is written in the painting, a prayer learned by the believers from the Church "St.

${ }^{33}$ Candid MuşleA, in "Foaie pentru Minte”, no. 10/1853, p. 78.

${ }^{34}$ Candid MuşLeA, Biserica Sfântul Nicolae ..., vol. 1, p. 197

35 Nicoae IORGA writes that the first is "the painter from Craiova, who also painted the Chapel of Bethlen from Blaj" in IDEM, Scrisori şi inscripţii ardelene şi maramureşene, vol. II. 
Nicholas" in their childhood days ${ }^{36}$.

The exterior painting of the chapel is placed around the fresco of the Assumption of Virgin Mary, together with themes, such as the miraculous appearance of the apostles, The Holy Trinity, the Coronation of Virgin Mary, the Annunciation, the Entrance into the temple of the Virgin, the Tree of Jesse - a representation of the genealogy of Christ and the Synod of the Virgin Mary. The cornice of the chapel walls is decorated with vegetal and floral motifs, also found in the chapel built by Hagi Radu Inaşu and painted by the painter Ioan. The same motifs are placed around the eastern window of the chapel and around the medallions on the western and northern arches, where Jesus Christ between Virgin Mary and John the Baptist, the Apostles Peter and Paul and the Evangelists John, Luke, Matthew and Mark are represented. The exterior fresco of the chapel is probably the first representation of this type in the north of the Carpathians during the $18^{\text {th }}$ century, with the help of the painters from Oltenia, a type of painting that eventually extends in the south of Transylvania ${ }^{37}$.

c) The chapel of the Ascension of the Lord was started in 1749 by the archpriest Eustachie Grid after he began raising the necessary sum in 1744 from donations, including from Czarina Elisabeta Petrovna - 2500 de roubles - and some important merchants from Braşov, such as Radu Pricop and his wife Parascheva, or Hagi Pricup and his wife Anastasia ${ }^{38}$, also "the chief of the merchants", Apostol Manu, the representative of Constantin Brâncoveanu in Cetatea Braşovului ${ }^{39}$. As in the case of the Chapel of Annunciation, the Saxon Magister tries to block the construction, but Eustachie Grid is decisively supported by Elisabeta Petrovna, also by Grigore II Ghica of Wallachia (1733 - 1734, 1748 - 1752). The intervention of the Czarina to Maria Teresa brings temporary suspension of the unionist pressures from the Court of Wien $^{40}$. The chapel, with dimensions of $12.20 \mathrm{~m} \times 6.20 \mathrm{~m}$ is finished in 1752. According to the Cyrillic inscription from the oblation table, the

\footnotetext{
${ }^{36}$ Vasile Oltean, Configuraţia istorică ..., p. 212.

${ }^{37}$ Marius PORUMB, Dicţionar de pictură veche românească din Transilvania sec. XIIIXVIII, Bucureşti, Editura Academiei, 1998, p. 51.

${ }^{38}$ Candid MușLEA, Biserica Sfântul Nicolae..., p. 54;

${ }^{39}$ Ibidem, vol. II, p. 54.

${ }^{40}$ Ibidem, p. 14.
} 
paintings belong to the Wallachian painters Ioan, Iancu, Constantin and Irimie $^{41}$. They show a series of biblical scenes, such as the parables of the Saviour ${ }^{42}$. The painting Jesus Pantokrator painted in warm tones, is surrounded by the inscription "God is looking down from the sky to see if anyone recognizes the True Son of God". The big prophets and apostles are painted on the tower of the navel and the four Evangelists are placed on the pendants. The arches are decorated with saints surrounded by floral medallions with Transylvanian motifs. The lateral walls of the navel are decorated with frescoes depicting military saints and evangelical scenes - The Annunciation, The Birth of Jesus, The Baptism of the Lord, The Passions of Christ, The Crown of Thorns, The Crucifixion, also The Parable of the Rich Man, and The Healing of the Blind Man. The eastern wall of the church porch and part of the canopy are painted with scenes from the Last Inquest. The scenes of Heaven and Hell are impressive and bear the inscriptions: "Come, blessed people of My Father, inherit the Kingdom prepared for you since the beginning of the days" and "Go away, cursed by the eternal fire prepared for the devil and his servants". Outside, the walls were partially painted, nowadays being better preserved the 17 medallions of the prophets, placed under the projecting roof, decorated at its turn with vegetal and geometrical motifs. Each character has a word under the medallion, all the words forming the text from Matthew 10:38: "Whoever does not take up their cross and follow me is not worthy of $m e^{\text {"43 }}$. Related to this evangelic command, on the south and east façades, there are scenes related to the martyrdom of St. Stephan, the beheading of Saint John and the finding of his head. The Holy Trinity is represented in the superior part. The facades of the south apse, The Good Shepard, St. Spiridon, Jesus Christ and St. Basil are represented ${ }^{44}$. The entire painting of the chapel - unitary in conception and technique bears the mark of the painters Ioan and Iancu, who also signed the paintings from the tympanum. This painting with Byzantine origins ${ }^{45}$ is characterized by sobriety and also by the beauty of the characters,

\footnotetext{
${ }^{41}$ Candid MușLeA, Biserica Sfântul Nicolae..., vol. II, p. 60.

42 Nicolae IorgA, op. cit., p. 101.

${ }^{43}$ Candid MușLeA, Biserica Sfântul Nicolae..., vol. II, p. 68.

44 Vasile Oltean, Configuraţia istorică ..., p. 215.

${ }^{45}$ Ibidem.
} 
highlighting a more human perspective in the understanding of the art, compared to the previous ascetic one $e^{46}$. This feature provided me with a new artistic expression that will lead to a more pregnant awareness connected to the Romanian national and confessional identity, reflected in the frescoes and the icons with Byzantine character that will borrow more decorative elements from the Romanian popular art.

\section{Conclusions}

The chapels of the Church "St. Nicholas", built in the $18^{\text {th }}$ century by the archpriests Radu Tempea II Cronicarul and Eustachie Grid, their iconography and paintings, illustrate in a significant manner the way that Transylvanian Orthodoxy, in general, and Orthodoxy from Thara Bârsei especially, acted in a period of intensified pressure against them in religious teaching and practice, as well as to the spirituality of the eldest and numerous inhabitants in Transylvania. Thus, the building and the painting of the two chapels testifies to the determination of the Romanians, clergy and laymen, to remain Orthodox just as their ancestors did, in spite of all kinds of pressures, direct and effective, coming from the Saxon Lutherans, or, more subtle and more acute, generated by the Hungarian Catholics supported by the Court of Wien. At the same time, the way the two chapels were painted, combining successfully the Byzantine style and some autochthonous approaches, as well as themes with undebatable origin, highlight, as any other intellectual creation related to the Church, the determination of the involved people - painters, clergy, donators and supporters - to remain active in Orthodoxy, completely aware of their meaning and role. Simultaneously Byzantine and autochthonous, the iconographic painting of the two chapels highlights the reality of the Romanian Orthodoxy, through a spirituality that left a Romanian mark on the patrimony of the Constantinopolitan Church, a style that proved to be strong as armor. At the same time, to a specialized viewer, the icons and the frescoes show the metamorphosis of the Byzantine tradition in the Romanian space, first in Wallachia and later in Transylvania, through a Serbian path, when the Serbian kingdom adopted the style of the Palaeologus, in

46 Teodora Voinescu, The Post-Byzantin icons în Moldavia and Valachia, London, 1952, p. 375. 
$1321^{47}$. Thus, discussing the religious paintings from the $18^{\text {th }}$ century, we have to mention its value of artistic synthesis, expressed by Nicolae Iorga through the formula "Byzantium after Byzantium". The autochthonous element is only a component in this huge synthesis, e.g., the orientation of the tendency of emphasizing, beyond the Balkan stylistic diversity to which it was in contact to, the originality of the Romanian specific elements. If, through the first specific feature, the Romanians affirmed their oriental faith by maintaining relations with the Orthodox hierarchy from Wallachia and the Imperial Russia of Elisavetei Petrovna, the priests receiving teachings from the Wallachian hierarchs or being ordained there, the second feature shows the great openness of the priests from the Church "St. Nicholas" of Şcheii Braşovului, for an architectonic and painting dialogue, in the $18^{\text {th }}$ century, maintaining the religious autochthonous element, creating a hybrid style, still authentic Romanian, mirrored in the mural paintings and in icons, where the holy characters have an appearance more human than ascetic, if compared to the previous periods, with faces presenting individual features and the feelings of the Orthodox faith.

\section{References}

1. Angelescu, Mariana / Dobriceanu, Alexandru, "O descoperire recentă. Vechiul parament al Bisericii din Şcheii Braşovului", in Astra no. $5 / 1968$.

2. DRAGOMIR, Silviu, Istoria dezrobirii religioase a românilor din Ardeal in secolul XVIII, vol. I, Sibiu, Tiparul Tipografic al arhidiacezanei, 1920.

3. DRĂGUȚ, Vasile, Romanian Art: Prehistory, antiquity, middleages, renaissance, baroque, Bucureşti, Meridian, 1984.

4. GRECEANU, Eugenia, "Pătrunderea infulenţelor de tradiţie bizantină în arhitectura bisericilor româneşti din Transilvania (până la sfârşitul veacului al XVI-lea), in SCIA, no. 2/1972.

5. IORGA, Nicolae, "O descoperire privitoare la Biserica Sfântul Nicolae din Şcheii Braşovului", in Memoriile Academiei Române (secț. ist.), no. 22/1938, Bucureşti.

Vasile Drăguţ, Romanian Art: Prehistory, antiquity, middle ages, renaissance, baroque, Bucureşti, Meridian, 1984, p. 116. 
6. IORGA, Nicolae, Artă nouă şi veche în Ardealul anului încoronării, Bucureşti, 1923.

7. LuPAŞ, Ioan, Documente istorice transilvănene, vol. I, Cluj, Cartea Românească, 1940.

8. Munteanu, Luminiţa / Beldie Mariana, "Rezultatele cercetărilor arheologice la Biserica Sfântul Nicolae din Şcheii Braşovului - etapa 1975", in MIA, no.1/1976.

9. MuşleA, Candid, "Biserica Sfântul Nicolae din Şcheii Braşovului", vol. I: 1292-1742, în Astra, no.1/1946, Braşov.

10. MuşLeA, Candid C., "Biserica Sfầntul Nicolae din Şcheii Braşovului", vol. II: 1743-1837, în Astra, no. 1/1946.

11. NussbaCHER, Gernot, Caietele Corona-Contribuţii la istoria Braşovului, CAIETUL 2, Braşov, Aldus, 2003.

12. Oltean, Vasile, Configuraţia istorică şi bisericească a Braşovului ( $\sec$ XIII-XX), Sibiu, Andreiană, 2010.

13. Oltean, Vasile, Moartea lui Mihai Viteazul, Braşov, Ermetic, 2001.

14. OltEAN, Vasile, Şcoala românească din Şcheii Braşovului, Bucureşti, Ştiinţifică şi Enciclopedică Ph, 1989.

15. PoP, Ioan, "Date arheologice privitoare la istoria Braşovului în secolele IX-XII", in Cummidava, II, Braşov, 1968.

16. PORUMB, Marius, Dicţionar de pictură veche românească din Transilvania sec. XIII-XVIII, Bucureşti, Editura Academiei, 1998.

17. StingHE, Sterie / ŞCHIAU, Octavian / Bot, Livia, RaduTempea Istoria sfintei besereci a Şcheilor Braşovului, Bucureşti, Editura pentru Literatură, 1969.

18. STINGHE, Sterie, Documente privitoare la trecutul românilor din Şchei 1700-1795, vol. V, Braşov, 1901-1907.

19. SUlICĂ, Nicolae, Cronica protopopului Vasile din Braşov, Sibiu, 1943.

20. VoInescu, Teodora, The Post-Byzantin icons în Moldavia and Valachia, London, 1952. 